\title{
Инфракрасная радиометрия на основе многорядных инфракрасных фотоприемных устройств
}

\author{
К.О. Болтарь ${ }^{1,2)}$, И.Д. Бурлаков ${ }^{1,3)}$, С.В. Головин ${ }^{1)}$, А.В. Никонов ${ }^{1,2)}$, Н.И. Яковлева ${ }^{1)}$ \\ ${ }^{1}$ АО «НПО «Орион», Москва, 111538, ул. Косинская, 9 \\ ${ }^{2}$ МФТИ, Москва, 117303, ул. Керченская, д. 1А, корп. 1 \\ ${ }^{3}$ МИРЭА - Российский технологический университет, Москва, 119454, проспект Вернадского, 78
}

DOI 10.34077/RCSP2019-61

В основу принципа действия инфракрасных радиометров положено преобразование ИК-излучения от объектов наблюдения в электрические сигналы, на основе которых формируется видимое изображение или задается механизм обработки параметров наблюдаемых объектов при различных фоновых потоках. Для работы в заданных диапазонах ИК области спектра радиометры включают в свой состав специальные крупноформатные, высокочувствительные фотоприемные устройства (ФПУ), использующие матрицы фоточувствительных элементов (МФЧЭ) с обработкой данных в БИС считывания. Среди различных полупроводниковых материалов, чувствительных в ИК области спектра, тройные растворы $\mathrm{HgCdTe}$ являются лучшим полупроводниковым соединением с точки зрения достижения максимальных фотоэлектрических параметров $[1,2]$ в заданных ИК диапазонах спектра, что связано с выбором архитектуры фоточувствительных элементов с уменьшенным влиянием тепловых процессов при детектировании излучения.

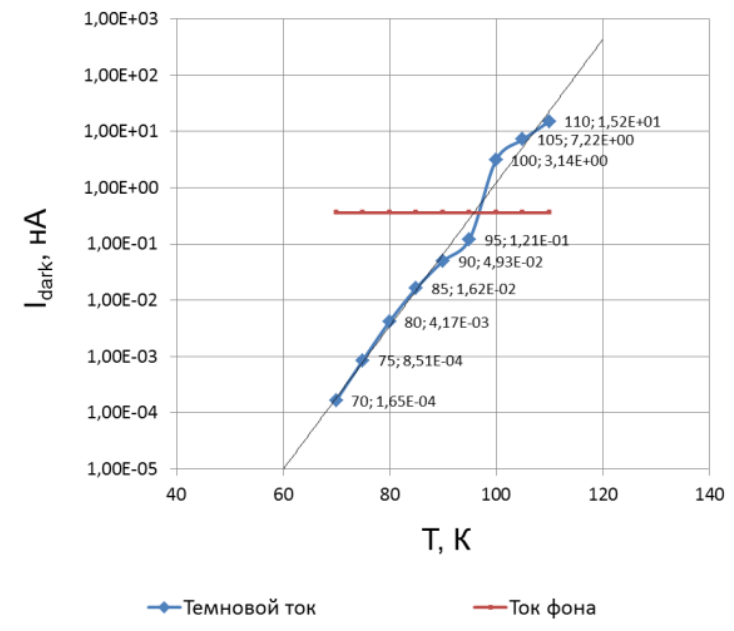

Рис. 1. Температурные зависимости темнового тока ФПУ средневолнового спектрального диапазона $\Delta \lambda=3,5-4,1$ мкм
Для включения в состав инфракрасного радиометра изготовлены по планарной технологии на основе гетероэпитаксиальных структур с поглощающим слоем $\mathrm{HgCdTe} p$-типа проводимости ФПУ, чувствительные в средневолновом и длинноволновом ИК диапазонах спектра. Проведены исследования темновых токов и шумов фоточувствительных элементов (ФЧЭ) многорядных фотоприемных модулей на основе гетероэпитаксиальных (ГЭС) структур $\mathrm{HgCdTe}$ с шагом 28 мкм средневолнового и длинноволнового ИК диапазонов спектра при обратном напряжении смещения $V=-0,1 \mathrm{~B}$. На рис. 1 показана температурная зависимость темнового тока для образца средневолнового диапазона спектра $(\Delta \lambda=3.5-4,1$ мкм). Значение обнаружительной способности $\quad D^{*} \geq 10^{12}$ для ФПУ средневолнового диапазона достигается при темновых токах менее $10^{-11} \mathrm{~A}$, что достижимо для температуры охлаждения $T=80 \mathrm{~K}$.

Проведены теоретические и экспериментальные исследования величин и источников выходного шума ФПУ длинноволнового ИК диапазона спектра в зависимости от времени накопления в диапазоне $\mathrm{T}_{\text {нак }}=25-200$ мкс. Показано, что шум прибора включает шум ФЧЭ и входной ячейки считывания мультиплексора. Шум фотодиода он включает шум ячейки считывания, который должен быть существенно меньше шума фотодиода, а емкость накопления ячейки считывания для ФПУ длинноволнового диапазона должна быть менее 10 фФ.

\section{Лumepamypa}

[1] Rogalski A., HgCdTe infrared material: History, status, and outlook // Rep. Prog. Phys., 68, 2267-2336 (2005).

[2] K.O. Boltar, I.D. Burlakov, A.M. Filachev, N.I. Yakovleva, MCT LWIR 6×576 FPA, // Applied Phys. (rus). No 3, 2012, pp.61-65. 